\title{
THE CURRENT STATE OF ENTREPRENEURIAL COMPETENCE FORMATION OF BACHELORS IN THE ENTERPRISE ECONOMICS
}

The article considers the current state of entrepreneurial competence formation of future bachelors in the Enterprise Economics in the professional training process. The analysis of the entrepreneurial competence content is presented in the context of the competence approach, with regard to entrepreneurship, as a leading form of management in market economy conditions. The current state of competence formation of future bachelors in the Enterprise Economics is defined as the process of the future bachelor's professional training in the Enterprise Economics, which is influenced by the general modern education content of our state. The article shows that the current state of entrepreneurial competence is a separate unit in the future bachelors' curricula, in which elements of academic and vocational education are gradually implemented, which are fixed in the process of practical training during the entire period of professional training in the Enterprise Economics.

The analysis of scientific works has shown that economic thinking, training in marketing area, discipline, initiative, sense of responsibility, communicativeness, creative attitude to work occupy an important place in the future bachelors' entrepreneurial competence structure in the Enterprise Economics.

According to the results of the research, future bachelors training in the Enterprise Economics at National Transport University, we have found out the current state of specialists entrepreneurial competence formation of this specialty. The future bachelors acquisition in the Enterprise Economics in the process of professional training the integral, general and professional competences is analyzed.

Keywords: future bachelors, entrepreneurship, Enterprise Economics, entrepreneurial competence, key competence.

Problem Statement: In current world of economic science, there is an active knowledge economy development, where knowledge plays a crucial role, and knowledge production becomes a source of economic growth and formation of an innovative economy based on knowledge, innovation, positive perception of new ideas, systems, technologies, readiness for their practical implementation in various spheres of human activity.

Most researchers point out that there have been recent changes in national higher economic education. In particular, the number of higher education institutions (HEls) of economic direction of the III - IV levels of accreditation, including non-state forms of ownership, has increased; opportunities for higher education acquisition in certain specialties have been expanded to meet the needs of a market economy (economics and entrepreneurship, management, marketing, accounting and auditing, banking and insurance). The rapid development of these directions testifies to the implementation of policies aimed at the economic growth of Ukraine.

The current processes of reforming the national education system highlight the ideas of economic preparation in the HEI on the plan of ensuring competitiveness, which is related primarily to the application of the continuous economic education model [6,p.81-85].

At the same time, there are a number of problems in the national economic science related to the substantiation of the scientific practical expediency of the Ukrainian economy scientific researches as an independent economic system of a new type with its features that characterize the transit period.

Researchers V. Vachevskyi, L. Kozachok, N. Prymachenko highlight the following: knowledge, experience, skills, abilities, professionally significant personality traits that a specialist needs in order to fulfill his / her professional duties, considering certain aspects of professionalism.

Sources. Some aspects of the professional traits formation for future professionals, favorable for opening their own business, were considered in the works of such Ukrainian researchers as D. Zakatnov, L. Yershova, $\mathrm{V}$. Radkevych and others. For the most part, these issues were analyzed in the context of the establishment and functioning of careers centers, the organization of career counseling and the formation of career competences of students. M. V. Vrachevskyi, Y. A. Ivanchenko, O. S. Padalka and other, offer to build continuous economic education on the basis of a competent approach, because in current conditions it is first and foremost important to clearly define the socio-economic roles of bachelors in Economics, without which it is impossible to form a system of requirements for their professional training [2].

At the same time, it is promising to define and substantiate the current state formation conditions of bachelor's entrepreneurial competence in the Enterprise Economics.

The purpose of this article is to analyze the entrepreneurial competence formation of future bachelors in the Enterprise Economics on the basis of scientific literature study; to consider the content of the competence components in the context of their professional training.

Research methods are conditioned by its interdisciplinary character, use of achievements of economic, psychological and pedagogical sciences, in particular, Enterprise Economics, Organization of Enterprises, Psychology, Pedagogy etc. Research on the entrepreneurial competence formation of future bachelors in the Enterprise Economics in the process of professional training is based on the methodological principles of objectivity, causality, validity and social direction. Since the object of the research and the logical and activity operations are aimed at its comprehension, such principles of scientific search as objectivity, functionality and structure are applied in the unified process of research. The presence of different approaches to studying the entrepreneurial competence formation led to the choice of research methods, in particular, system-structural, systemcomponent and system-functional analysis.

Presenting main material. The essence of the competency approach involves changes in the formation of learning goals, expected learning results as a complex of competencies needed to accomplish different economic tasks. A competent approach can be seen as an attempt to approximate the training of future specialists in the Enterprise Economics to the needs of the labor market and employers.

The concept of a competent education becomes one of the leading in economic education, and a competent approach enhances its practical orientation, its subjectprofessional aspect, emphasizes the role of experience and ability to practically solve problems.

In order to ensure the correspondence of the national economic education to the current requirements, it is important to create and substantiate theoretical models of introducing an innovation-oriented approach to the 
professional training of specialists in the Enterprise Economics. These models should be based on preparing individuals for innovation activity in the economic sphere. Of particular importance is the competent approach in the future specialists training in the Enterprise Economics. Professional training of bachelors in the Enterprise Economics in the educational process of higher education institutions is carried out by filling economic disciplines with innovative scientific and practical information that forms relevant professional skills, in particular entrepreneurial competence. At the same time, the problem of forming the key and informational competences necessary for future economists to start their own business remains unresolved in higher education institutions. This is due to the critical reduction of the socio-humanitarian component of higher economic education and insufficient systematicity in the competencies formation of future specialists. Improvement also requires the use of a competent approach in the education content formation in most higher education institutions $[4 ; 3$, p. $165 ; 5 ; 10 ; 12$, p. $5 ; 13$, p. 10; 14].

In current conditions of social development, the orientation of economic education on the innovative personality traits formation becomes especially important. The term "entrepreneurial competence" is widely used when considering problems of educational innovation and defining requirements for graduates of $\mathrm{HEI}$. Considering entrepreneurial competence, researchers S. Melnyk, O. Topol, V. Dryzhak, D. Zakatnov, N. Pasichnyk, N. Pobirchenko [5, p. 173-179] distinguish the following competencies in its composition:

- communicative - knowledge of business etiquette, understanding and interaction;

- informational - application of necessary technologies and programs to search for the necessary information;

- professional (spheres of economic activity) - a system of knowledge and skills in the field of national and world economy, analysis and design, making management decisions.

Following the authors, we consider such components of the entrepreneurial competence of bachelors in the Enterprise Economics, which are formed in the process of professional training, such as economic thinking; training in marketing; discipline; initiative; sense of responsibility; communicativeness; creative attitude to work. But most importantly, the content of the economic professional's competence should include thorough economic knowledge and awareness of legal and social issues.

These traits are components of entrepreneurial competence, the current formation state of which is not sufficiently disclosed for future specialists in the economic profile. Therefore, one of the main tasks in the context of the vocational training productivity improving is to review the economic education content structure at all levels of vocational training.

These changes are primarily related to the conceptual approach to the state of entrepreneurial competence formation. After all, its formation is an important component of the professional outlook of the future bachelor in the Enterprise Economics, which is acquired in the process of professional training, as a bearer not only of economic knowledge, but also models of entrepreneurial activity and economic culture; mastering the relevant skills and ability to be mobile in accordance with changes and directions of professional activity. These requirements must be met by educational training programs for future specialists in the Enterprise Economics.

Entrepreneurial competence has a multi-level formation and multicomponent structure that can be represented by the unity of axiological, acmeological, cognitive and empirical components. The essence of the axiological component includes such concepts as "values", "meaning", "evaluation", which are necessary in public life and being in social institutions. The acmeological component of entrepreneurial competence is presented as the need to increase the level of each component of entrepreneurial competence, the desire for self-realization. The cognitive component is a complex of scientific and theoretical knowledge, practical skills and abilities in the economic sphere, knowledge of laws, theories, definitions, basic economic systems and entrepreneurial law. The empirical component is decisive in the formation of entrepreneurial competence, because it forms a specialist with thorough knowledge and experience in entrepreneurial activity.

The modern paradigm of higher economic education, in particular the entrepreneurial competence formation of bachelors in the Enterprise Economics in the process of professional training is considered as a process of mastering in the $\mathrm{HEl}$ the ability to determine the borders and opportunities to apply a competent approach to education, which highlights not the specialist awareness but the ability on the basis of knowledge and practical skills to solve problems that arise in everyday life. Economic education is one of the most important people adaptation forms to new rapidly changing living conditions.

In the information society, traditional education is gradually losing its importance. The enormous flow of information that becomes obsolete faster than a student completes studying in the system of formal education is no longer possible to fit into the curriculum. The need to overload the memory of the future specialist with additional knowledge does not make sense. It should be taught to find and use them by themselves. Therefore, an effective tool for improving the education quality is the use of a competent approach to education, which highlights not the student's awareness but the ability to solve problems that arise in everyday life, on the basis of knowledge, abilities and skills (competences).

Current tasks of economics lecturers include:

- ensuring the formation of knowledge and skills for analyzing economic events in society, for understanding the realities of the surrounding world;

- promotion of creative thinking development, as well as the skills formation for critical analysis and objective assessment of the economic situation, making independent decisions.

It is during the study of economic subjects that students gain economic experience, which is important for planning their future life and career. In this regard, innovative pedagogical technologies, which create the conditions for the formation of a comprehensive, developed competent person, are used in the teaching of economic disciplines. The educational process is enhanced by using the active and interactive teaching methods aimed at the development of creative thinking, the formation of independence, determination, responsibility, the ability to adapt flexibly in changing life situations, to think critically, to be sociable, to work in a team.

Achievements of professors in economics N. M. Bondar and A. Y. Spitsyna at National Transport University shows that it is conducting the innovative classes (business games, conferences, brain-rings, economic "expeditions", etc.) that help to increase student success, make learning more interesting and varied [16, p. 130-135.]. Of particular interest are couples in the form of discussions, brainstorming, conferences involving dialogue, discussions about the resolution of any problem. Most students listen to the 
opinions of others, learn to defend their point of view, to be confident, independent, resolute.

When conducting classes, it is effective to use research tasks, where students need to be able to find information from different sources, use reference literature, online resources, media, statistic data. In such activities, students learn how to analyze, systematize the results obtained and draw appropriate conclusions. Self-search activity promotes the formation of new knowledge, develops creativity, erudition, ability to work in a team. These types of activities are used in conducting classes in Economics on various topics, in particular: "Entrepreneurship", "State Budget", "Entrepreneurship as a form of activity in a market economy conditions", "Inflation" and others.

Modern classes cannot be imagined without the use of the latest technologies, especially interactive education, involving each student in the use of tasks corresponding to the level of his / her educational achievements. The use of cooperative education technology promotes the formation of communication skills, ability to work in a team. Thus, social and communicative competences are formed. An important technology in the process of key competencies formation is the project method and such technology of study as research. Working on project creation promotes the key competences formation (communicational, informational, creative, self-education and self-development). Future specialists produce creative, informational and research projects using computer technologies [9; 15; 11, p. 22-25p]. Such systematic work promotes education in the process of studying the economy of a competent person who possesses key competences and is capable of selfrealization in society.

All classes in professional economic subjects are very various. When teaching, demonstration programs, presentations, slideshows can be used. At seminars, students learn how to fill in tables, draw conclusions, and work with statistic data.

Multimedia technologies are one of the effective ways of motivating students to educational activities. One of the benefits is the ability for students to create presentations while working on projects, speeches etc. For example, students have a difficulties with learning the topic "Demand, Supply, Market Price". Multimedia technologies can allow showing demand and supplying schedules on an electronic whiteboard. A clear explanation of this law of economics contributes to a better understanding of the topic.

A creative approach to the design and conducting the seminar, a richness of various techniques, methods and forms of teaching can ensure its effectiveness. The educational process is designed so that future specialists in the Enterprise Economics will learn first of all to understand themselves and to realize their knowledge and experience in everyday life [7].

Innovative pedagogical activity is specific and quite complex and requires special knowledge, skills and abilities. The implementation of innovations is impossible without a teacher-researcher who has a systemic thinking, developed ability to creativity, formed and conscious willingness to innovate. There are two ways for each of us: living past our merits, turning a blind eye to dramatic change in the world, condemning our students to life failure, or trying to change something in their attitude to the latest educational technologies. You can mourn lost ideals, complain about the decline of spirituality and upbringing, loss of humanity and morality, in general, life and quite unusual learning, but the course of events will not be returned[1].

One of the most important strategic tasks at the present stage of vocational education modernization is to ensure the training quality of a competent graduate at the level of international standards. This problem can be solved under the conditions of changing pedagogical methods and introduction of innovative pedagogical teaching technologies.

Having analyzed the educational training program of bachelors in the Enterprise Economics at the National Transport University, it is revealed that in the process of professional training future specialists acquire the following competencies:

- integral competencies - the ability to solve complex specialized tasks and practical problems in a given field of professional activity or in the process of studying, which involves the application of certain theories and methods of the relevant science (in particular, methods of mathematical modeling, socio-economic forecasting, computer data processing and model construction, statistical and analytical methods and models) and is characterized by complexity and uncertainty of conditions.

- general competencies - which in turn consist of:

1) the ability to generalize, analyze and process information, formulate a goal and choose ways to achieve it.

2) the ability to understand and analyze worldview, socially significant philosophical problems.

3 ) the ability to understand the driving forces and patterns of historical process, events and processes of economic history.

4) the ability to analyze the economic problems and processes that occur in society, to forecast their possible development in the future.

5) the ability to use regulatory documents in economic activity.

6) the ability to communicate in their mother tongue, both orally and in writing.

7) the ability to work in a team, willingness to interpersonal interaction.

8 ) the ability to make justified decisions, evaluate them and ensure the high quality of these decisions implementation.

9) the ability to work independently, including using distance learning forms.

10) the ability to be critical and self-critical.

11 ) the ability to act socially, responsibly and civilly consciously.

12) skills in using information and communication technologies.

13) the ability to communicate in a foreign language.

14) the desire to preserve the environment, respect the concept of safety.

$15)$ the ability to work in an international context.

16) the ability to take initiative, generate new ideas (creativity).

- professional competencies include:

1) the ability to perform informational and analytical support for the development and analytical evaluation of current plans, budgets and strategic forecasts of the enterprise activity.

2 ) the ability to use methods and tools of resource analysis to formulate business process development options.

3) the ability to plan and forecast social and financial and economic indicators of current and strategic activity of economic entities, to analyze and control the process of their implementation.

4) the ability to ensure the functioning of modern business models of companies.

5 ) the ability to research and analyze perspective directions of international economic relations development, 
to calculate and substantiate the main economic indicators of foreign economic business entities activity.

6 ) the ability to determine the optimal capital structure, choosing rational forms of financing the enterprise to ensure the goals of focused activities.

7) the ability to identify and evaluate the costs of the enterprise in order to form a management system as a factor in improving the efficiency of enterprises economic activity.

Bachelor's skills are defined by such types of educational activity as the concretization of general and professional competences in programs of studying disciplines, practices, individual tasks and are used as criteria for the selection of necessary and sufficient knowledge (content modules), which can be identified, quantified and measured. Connection of the educational program with the training programs by type of studying activity ensures the quality of higher education at the design stage. The specialist should have a high level of professional training, which requires a broad liberal arts education, which includes mastering the necessary knowledge in the field of philosophy and the legal bases of education; provides the necessary level of communication for the specialist in the fields of professional and situational communication in a foreign language; forms an intellectual, creative personality, which has its own original oratorical style, possesses the art of persuasive speech.

University graduates with economist qualifications may perform production and financial work at transportation enterprises and enterprises of other fields of the country's economy in such positions as economist, auditor for production, technical and economic issues, financial and economic security specialist, assistant manager of production department, referent, organizer of record keeping, planning technician, economist-statistician etc.

Analyzing the existing educational and professional training program of bachelors at NTU, it can be seen that the regulatory disciplines are $83.75 \%$, selective $-16.25 \%$, while the theoretical part is $75 \%$, and practical $-25 \%$. In such distribution of studying disciplines, the priority belongs to the theoretical part (which is very necessary), but in terms of practical classes, their number needs to be increased, because the qualitative structure of the entrepreneurial competence formation is impossible without the through practice of applying methods, technologies, projects, trainings, individualization of education.

Conclusions. The results of the economic and pedagogical literature analysis made it possible to reveal the current state of professional competences formation for the students of $\mathrm{HEl}$, who receive a bachelor's degree in the specialty 051 "Enterprise Economics". Most researchers distinguish communicative, informational, and professional skills within the future economist competencies. The educational program analysis of the specialty "Enterprise Economics" shows that students acquire integrated, general and professional competences, but reveals the need to strengthen the practical component in the educational process. It has been found that entrepreneurial competence combines acmeological, axiological, cognitive and empirical aspects. It is shown that entrepreneurial competence is not allocated as a separate unit in the current curricula of future bachelors, where the elements of academic and professional education, which should be fixed in the process of practical training during the entire period of specialists studying in the Enterprise Economics, are phased out.

The current tendencies of introducing entrepreneurial competence in the higher education system of Ukraine, in our opinion, depend on the economic transformations that form the need for specialists of the appropriate level, the readiness of students to realize their personal potential in the professional training process of bachelors in the Enterprise Economics. Further research will focus on developing a model of professional training for future bachelors in the Enterprise Economics and on analyzing existing problems and prospects for entrepreneurial competence formation.

References

1. Volgina, L. and Bogoslov, I., 2007. Organization of project activity. Head 4, $99 \mathrm{p}$.

2. Vrachevskyi M. V. 2005. Marketing. Formation of professional competence: a textbook. Publishing House "Professional", 512 p.

3. Yershov, L, 2018. Transformation of the students values system in the reforming national vocational education context. Scientific announcer of the Institute of Vocational Education of the National Academy of Pedagogical Sciences of Ukraine. Professional Pedagogy, 16, p. 162-168.

4. Yershova, L., 2015. Formation of a reference personality as a problem of modern Ukrainian educational policy. Bulletin of Cherkasy University. Pedagogical Sciences, 6 (339), p. 119-124

5. Zakatnov, D., 2009. Status and Problems of Vocational Orientation. Vocational education: innovative experience, prospects, 6, p. 173-179.

6. Zakhariev, V.V., 2007. Innovative challenges for the education system in the conditions of economic knowledge. Innovation, 4, p.81-85.

7. Kyrylenko, V., 2005. Impaired learning motivation as the root cause of negative behavior. Psychologist, 18, pp.7-8

8. Kravets, S., 2014. Formation of key competences in the professional training process of future restaurant service specialists: results of pedagogical experiment. Vocational education: problems and perspectives, 6, p. 105-110.

9. Kulalaieva, N., 2016. Project training as a condition for gaining experience of safe work by future builders. Scientific Bulletin of the Institute of Vocational Education of the National Academy of Pedagogical Sciences of Ukraine. Professional Pedagogy, p. 69-77.

10. Odnoroh, H., 2019. The essence and structure of key competencies of future skilled sewing workers. Scientific Bulletin of the Institute of Vocational Education of the NAPS of Ukraine. Professional Pedagogy, 18, p. 31-36. https://doi.org/10.32835/2223-5752.2019.18.31-36

11. Peleheichenko, V., 2009. Conditions of organization of project activity. Open Lesson, 4, p. 22-25

12. Radkevych, V. O., 2006. Research principles of vocational school teacher activity. Vocational Education, 4, p. 5-7.

13. Radkevych, V. O., 2012. Competent approach to quality assurance in vocational education and training. Scientific and methodological support of vocational education and training, 1, p. 9-15.

14. Romanova, H. M., 2009. Psychological and pedagogical training as a factor of the economic university teachers' professional self-realization. Bulletin of the University of Lviv, 3 (25), p. 167-175.

15. Romanova, H. M., 2014. Designing technologies for professional training of future skilled workers. Vocational education: scientific-methodical journal, p. 47-64.

16. Spitsyna, A. Y., 2014. Professional competence in the system of future economists professional training. Vocational Education: Problems and Prospects, 6, p. 130-135.

Список використаних джерел

1. Волгіна Л. та Богослов І., 2007. Організація проектної діяльності. Голова, 4, 99 с.

2. Врачевський М. В. 2005. Маркетинг. Формування професіонала компетентність: підручник. Видавництво "Професіонал", 512 с.

3. Єршов Л., 2018. Трансформація системи цінностей студентів у реформування національного контексту професійної освіти. Науковий диктор Інститут професійної освіти Національної педагогічної академії наук України. Професійна педагогіка, 16, с. 162-168.

4. Єршова Л., 2015. Формування референтної особистості як проблема сучасної української освітньої політики. Вісник Черкаського університету. Педагогічні науки, 6 (339), с. 119-124.

5. Закатнов Д., 2009. Стан та проблеми професійної орієнтації. Професійна освіта: інноваційний досвід, перспективи, 6, с. 173-179.

6. Захарєв В.В., 2007. Інноваційні виклики системі освіти в умовах економічного знання. Інновація, 4, с.81-85.

7. Кириленко В., 2005. Порушення мотивації навчання як першопричина негативна поведінка. Психолог, 18, с.7-8

8. Кравець С., 2014. Формування ключових компетентностей у професіонала навчальний процес майбутніх фрахівців ресторанного сервісу: результати педагогічного експерименту. Професійна освіта: проблеми та перспективи, 6, с. 105-110

9. Кулалаєва Н., 2016. Проектне навчання як умова отримання досвід безпечної роботи майбутніх будівельників. Науковий вісник Інституту професійної освіти Національної академії педагогічних наук Україна. Професійна педагогіка, с. 69-77.

10. Однорог X. 2019. Сутність та структура кпючових компетенцій Росії майбутні кваліфіковані швейні працівники. Науковий вісник Інституту професійної освіти Освіта НАПН України. Професійна педагогіка, 18, c. 31-36. https://doi.org/10.32835/2223-5752.2019.18.31-36

11. Пелехейченко В., 2009. Умови організації проектної діяльності. Відкритий урок, 4, с. 22-25. 
12. Радкевич В. О., 2006. Дослідницькі принципи професійної школи діяльність вчителя. Професійна освіта, 4, с. 5-7.

13. Радкевич В. О., 2012. Грамотний підхід до забезпечення якості в професійна освіта та навчання. Науково - методичне забезпечення професійна освіта та навчання, 1, с. 9-15.

14. Романова X. М., 2009. Психолого-педагогічна підготовка як фактор професійної самореалізації викладачів економічного університету. Вісник Львівського університету, 3 (25), с. 167-175.
15. Романова Х. М., 2014. Проектування технологій для професіоналів підготовка майбутніх кваліфікованих робітників. Професійна освіта: науково-методичний журнал, с. 47-64.

16. Спіцина А. Ю., 2014. Професійна компетентність у системі майбутнього економістів професійної підготовки. Професійна освіта: проблеми та перспективи, 6, с. 130-135

Надійшла до редколегії 24.12.19

І. Середіна, асп. ІПтО НАПН України

Національного транспортного університету, Київ

\section{СУЧАСНИЙ СТАН ФОРМУВАННЯ ПІДПРИЄМНИЦЬКОЇ КОМПЕТЕНТНОСТІ БАКАЛАВРІВ 3 ЕКОНОМІКИ ПІДПРИЕМСТВА}

Актуальність дослідження зумовлена інтенсивним розвитком вищої економічної освіти в Україні та гострим запитом суспільства й вітчизняної економіки на підготовку фахівців, готових до реалізації професійної кар'єри в умовах розвитку малого бізнесу. У статті розглянуто сучасний стан формування підприємницької компетентності майбутніх бакалаврів з економіки підприємства у процесі фахової підготовки. Аналіз змісту підприємницької компетентності подано в контексті компетентнісного підходу, з огляду на підприємництво, як провідну форму господарювання в умовах ринкової економіки. Сучасний стан формування компетентності майбутніх бакалаврів з економіки підприємства визначено як процес професійної підготовки майбутнього бакалавра з економіки підприємства, на яку впливає зміст загальної сучасної освіти нашої держави. У статті доведено, що сучасний стан підприємницької компетентності входить відокремленою одиницею до навчальних планів майбутніх бакалаврів, в яких поетапно реалізуються елементи академічної та професійної освіти, що закріплюються у процесі практичної підготовки протягом усього терміну навчання фахівців з економіки підприємства.

Аналіз наукових праць довів, що у структурі підприємницької компетентності майбутніх бакалаврів з економіки підприємства важливе місце посідають економічне мислення, підготовка у сферах маркетингу, дисциплінованість, ініціативність, почуття відповідальності, комунікативність, творче ставлення до праці.

За результатами дослідження підготовки майбутніх бакалаврів з економіки підприємства в Національному транспортному університеті, нами з'ясовано сучасний стан формування підприємницької компетентності фахівців даної спеціалізації. Проаналізовано набуття майбутніми бакалаврами з економіки підприємства у процесі фахової підготовки інтегральних, загальних та професійних компетентностей.

Ключові слова: майбутні бакалаври, підприємництво, економіка підприємства, підприємницька компетентність, ключова компетентність.

UDC 37.09

DOI: https://doi.org/10.17721/2415-3699.2020.11.12

K. Tulin, post-graduate,

Taras Shevchenko National University of Kyiv, Kyiv, Ukraine

\section{MODERN SYSTEM OF PEDAGOGICAL EDUCATION OF ROMANIA}

The article is a study of the main directions of the current system of pedagogical education in Romania. It is established that the current reform of Romania's education began in 2002 and aims at the gradual integration into the educational space of the European Union. The current structure of the Romanian education system is examined and each component is analyzed in detail. The system of preschool education organization and its division into age groups is defined. Highlighted on features of secondary education. It is established that secondary education starts from primary school and the defined of the assessment system at this level is determined. It is noted that starting from the fifth grade there is a transition to high school, where the system of assessment is changed to the ten-grade system. It is noted that high school has two components: compulsory education and senior-level grades. The training of specialists is carried out by public and private institutions that have autonomy in carrying out their training activities. It is determined that Romania's higher education system is divided into three stages. The first degree of higher education is considered, which envisages two study options and may last from four to six years depending on the chosen specialty. It is determined that the second higher education degree in Romania includes a master's program and a postgraduate program. It is established that the third level of higher education is a doctorate, which lasts from four to six years depending on the form of study and ends with the award of the doctor's degree after successfully defending the dissertation. The degree of education of pedagogical staff in the system of preschool and primary education, as well as the minimum requirements for their further professional training in higher education institutions, are determined.

Keywords: pedagogical education, Romania, primary education, secondary education, higher education.

Relevance of the research problem. The current state of development of the Ukrainian state is characterized by active integration processes in the field of education and culture and acceleration of the process of modernization of the entire education sector. National education should be developed in line with the requirements and recommendations of the European educational space, since the cultural rapprochement of countries while preserving their identity is a key trend in social development.

International documents of the General Assembly of the United Nations indicate that the promotion and protection of the rights of persons belonging to national or ethnic, religious and linguistic minorities contribute to the political and social stability of the countries in which they reside. Also focuses on the constant promotion and enjoyment of the rights of persons belonging to national or ethnic, religious and linguistic minorities as an integral part of society in general and in a democratic framework, based on the rule of law, and facilitates friendship and cooperation between peoples and states. This is addressed in particular in the Declaration on the Rights of Persons Belonging to National or Ethnic, Religious and Linguistic Minorities, adopted by General Assembly of the United Nations Resolution 47/135 of 18 December 1992. In today's conditions, we consider especially relevant the study of foreign experience of countries that have significant experience in this area and their implementation in national practice.

We consider Romania to be a neighboring country of the European Union with shared socio-historical experience, representing 15 minority communities and all of them fully provided at all levels (from kindergarten to high school) with educational materials, including electronic textbooks (which is also a separate issue for national education), which are freely available on the website of the Ministry of National Education of Romania. According to the latest data, in Romania, 142 new textbooks for schools that teach minority 